\title{
Language Learning Strategies of Graduates for Future Employment - An Overview
}

\author{
Kadzrina Abdul Kadir (Corresponding author) \\ School of Business Management, College of Business, Universiti Utara Malaysia \\ 06010 Sintok, Kedah, Malaysia
}

Tel: 60-4-928-5262Ｅ-mail: kadzrina@gmail.com

Wan Shakizah Wan Mohd Noor

School of Business Management, College of Business, Universiti Utara Malaysia

06010 Sintok, Kedah, MalaysiaＥ-mail: shakizah@uum.edu.my

Received: February 10, 2014 Accepted: March 6, 2014 Published: March 11, 2014

doi:10.5296/rbm.v1i2.5091ＵRL: http://dx.doi.org/10.5296/rbm.v1i2.5091

\begin{abstract}
English language fluency among graduates is becoming an important capability that graduates need for employment. The industry has noted the declining level of English among Malaysian graduates thus strategies and policies need to be implemented. This paper gives an overview on three areas of literature that is pertinent to this topic: competencies and future employment, language learning strategies and supplier learning. This paper suggest that a model for capability development from the area of supply chain management could be extrapolated as a framework for future research on analyzing the strategies that graduates employ on their own to improve their capability of English language fluency.
\end{abstract}

Keywords: language learning strategies, graduates, English, supplier learning, employment

\section{Introduction}

Some developing countries have set goals to achieve the level of developed country status within a set time frame. In order to achieve this goal, competencies have to be developed within the population in order that human capital of the country has the required talent to provide the skills needed within both global and local companies in the country as well as overseas. 
For Malaysia, the government has set in place to achieve developed country status by 2020, as had been set out in the Wawasan 2020 (Vision 2020) (Sarji, 1993). One of the key goals is to ensure that the population has achieved certain competencies that are needed. In the last decade, concerns of ensuring the quality of education would be improved have led to several initiatives by the government. In 2012, the Malaysian Education Blueprint had been presented to enable a revamped educational policy, including strategies to arrest the declining level of English among graduates and high-school leavers. This concern had been highlighted through reports and comments within mass media. The declining level of English among graduates was considered one of the factors for the existence of unemployability among some of the graduates. This was related to the comments from the industry as well as practitioners that the level of English among graduates was declining. As both private and public organizations are competing with global companies in a global arena, such concerns seemed valid.

The research literature has noted the assessment of the problem, whether looking at the decline in English, as well as overall competencies as well as the issues of employability of graduates. However, though programs have been implemented and research conducted on the various efforts to improve students' language learning as well as overall competencies, research is also needed to look at the students' own efforts. What are the students themselves doing about this? Is there awareness among the students themselves? Are they doing anything? This issue is also important for organizations themselves. When graduates as potential employees are found lacking, particularly in English language proficiency, employers either have to find other graduates who have the skills needed or get from other organizations ('buy') or train those employees themselves ('make'). This 'make-or-buy' dilemma is known among manufacturing organizations, but tends to be related to selecting suppliers, when referenced towards supply chain management. However, if organizations could recognize strategies or programs where the employees could 'train' themselves, with some support from organizations, thus this suggest that organizations could perhaps identify such employees or make available specific training to assist employees 'to learn how to learn', and in this case, English language proficiency. Thus literature on supply chain management and models of supplier development program could be extrapolated to view this issue.

This paper looks at the research literature, with particular emphasis on the Malaysian environment, and gives an overview of the three areas of literature that is related to this issueacquiring competencies and graduate employability, particularly Malaysia, English language learning strategies, and capability development through learning from supplier development programs. This paper then suggests research opportunities in the related area.

\section{Competencies and Graduate Employability}

Some countries have acknowledged that educational policy play a major role in the development of the nation and contributes to future growth. By ensuring heavy investment in education, the expectation is this strategy will contribute to economic growth of the country, through supplying and developing human resource and upgrading the capability of the human capital. Therefore, it is important that competencies are identified to ensure that through 
education, the students at all levels are being educated in the right arena towards future employability and thus contribute to economic growth of the country.

The issue of employability of graduates has become a concern in the last few years. Ismail, Yussof, and Lai (2011) noted that statistics from the Ministry of Higher Education Malaysia for 2008 and 2009 showed $24.1 \%$ and $26.7 \%$ respectively of graduates were unemployed six months after they graduated. Among the main reasons for being unemployed were because they were unable to find jobs $(71.8 \%)$ or jobs offered were not suitable $(18.4 \%)$ (Ismail et al., 2011).

Countries, such as the US and Australia, as well as Malaysia, have implemented changes in their education policy in order to ensure that generic skills would lead to competencies development and lead to growth, competitiveness and productivity (Marthandan, Jayashree, \& Yelwa, 2013). The authors stated that in Malaysia, the Ministry of Higher Education (MOHE, now the Ministry of Education) has implemented policies to ensure that Malaysia would achieve world class human capital. With the establishment of Malaysian Qualification Agency (MQA), the agency has established the Malaysian Qualifications Framework (MQF) to assess whether higher education institutions are able to provide environments where students are able to show that competencies were learned and this include: "knowledge, practical skills, social skills and responsibilities, values, attitudes and professionalism, problem solving and scientific skills, communication, leadership and team skills, information management and lifelong learning skills and managerial and entrepreneurial skills", and these competencies were divided into nine domains. (Marthandan et al., 2013).

In their research, Marthandan et al. (2013) investigated the competencies acquired by management students who had graduated and left the university minimum of a year. These students were surveyed on the competencies that were acquired during their studies. The authors' findings show that communication and teamwork were the competencies that were at the top of the nine domains, followed by managerial and entrepreneurial skills. The bottom of the list were the competencies of values, attitudes and professionalism, and above that was problem solving and scientific skills. The authors cautioned that the small sample in only two states in Malaysia could have an impact on the data collected. The authors suggest that the low showing of the values, attitudes and professionalism competency might suggest that students were lacking in self-confidence, and thus feel less able to train others. The authors suggest also that a possible impact on the findings could be that the majority of the students $(60 \%)$ had a CGPA of lower than 2.67. The study did not indicate emphasis on the ability of speaking English, but on the behavorial competencies of oral and written. Nevertheless, if the students were lacking in self-confidence and lacked the ability to speak English fluently (as might be extrapolated based on lower level of CGPA), this might have an impact on their future employment. The study indicated that out of 239 students, after nearly a year of graduation, $77 \%$ were employed while $16 \%$ were unemployed, with $7 \%$ either self-employed or furthering their studies. However, the study also indicated that the next level of competency developed were managerial and entrepreneurial skills. The authors suggest that students are confident of being managers. Overall, the findings as presented by the authors, could suggest that the competencies that universities and higher learning institutions need to 
focus on are values, attitudes and professionalism as well as problem solving and scientific skills. For graduates interested in working in multinational corporations, the two competencies found lacking could be the two most important competencies most favored by these organisations, in addition to fluent English.

Focusing on English language competency specifically, studies have shown that there is a global concern on the increasing gap between the level of competency of the graduates and the level needed for employment (Sarudin, Mohd Noor, Zubairi, Tunku Ahmad, \& Nordin, 2013). The authors noted that studies in Japan, Singapore, Hong Kong, Taiwan, Korea and Malaysia have mentioned the decrease in standards of English and this concern has led to these countries taking active measures to improve the standards, as English is considered the language of business and technology. In a 2005 news report based on a survey of 3,300 Malaysian human resource personnel, a key factor found to be the reason of high rate of unemployment among graduates was "weak English proficiency" (Sarudin et al., 2013). The authors implemented a mixed-method study in analyzing the needs of English language competency at the workplace from the perspective of employers as well as their view on the need of an English competency certification test, based on a survey of 295 companies from 14 industry sectors as well as focus groups and interviews of 15 human resource personnel. The authors reported a significant finding in terms of the favorability of establishing the English competency test that was 'valid, reliable, globally benchmarked and industry-driven...for non-native speakers of English' (p. 88, Sarudin et al., 2013). The study also discovered that English was the most important language at the workplace, that employers provide training programs to improve English language competency and English was assessed at all industry sectors at the recruitment process (Sarudin et al., 2013). The authors conclude that the reliability and validity of English competency certification test must be established, to avoid the concerns of employers regarding the reliability of current English language assessments in Malaysia. The authors suggest that employers need a certification test that "will allow employers to match candidates that best suit the job profile methodically, accurately and swiftly" (Sarudin et al., 2013, p. 93).

Another study which assessed employers' perception on Malaysian graduates focused on the services sector (Ismail et al., 2011). The authors had respondents who were made up of senior human resource managers in the services industry surveyed on graduates performance and the difference, if any, between local graduates and overseas graduates. Though overall the employers are satisfied with graduates' perforamance, there were still room for improvement. The authors found that the respondents felt that graduates needed to improve soft skills, which include communication skills, Malay and English language proficiency, writing skills, thinking skills, decision making and problem skills, ICT skills, team player, work planning, value and ethics, self-confidence, characteristic and attitude as well as leadership and personality. In addition, the authors found that employers felt that local graduates were better at skills among others such as problem solving and being a team player, while overseas graduates were better in study area, thinking skill and English language proficiency (Ismail et al., 2011).

The studies above indicate that Malaysian employers seem to regard that graduates' 
performance in soft skills, particularly English language proficiency could be much improved. Programs by the government such as the Malaysian Education Blueprint suggest policies and strategies are being implemented to improve the competencies of future graduates and if successful, the future graduates' performance might improve. However, what is the nation to do with the current graduates? Focusing on English language proficiency, the Malaysia Education Blueprint (2012) had highlighted one of the shortcomings of the current education policy, stating that teachers of English subjects needed upskilling as well as higher entry standards for teacher trainee programs. Meanwhile, the current graduates need strategies to 'upskill' their English capabilities on their own. The next section reviews the literature on learning strategies for both English as well as general learning strategies that are practiced by students.

\section{Language Learning Strategies}

Based on the literature, strategies for students use to study could be divided into three main categories (Al-Kadri et al., 2011). These strategies were based on three learning models (Broadbent, 1966): surface learning, deep level learning and strategic approach studying (Entwistle \& McCune, 2004). This was later revised to deep and reflective approach, superficial approach or achievement and effort approach (Al-Kadri et al., 2011). The types of strategies applied by students could change based on the environment and context and in their research, Al-Kadri et al. (2011) found that the factors that had an impact on students' learning strategies in the clinical medical environment were related to their teachers, whether as assessors, supervisors or source of stress (Al-Kadri et al., 2011). In analyzing these strategies deeper, the authors in a different paper found that though the literature suggest otherwise, self-assessment process was enhanced due to the feedback process rather than on merely the self-assessment process itself (Al-Kadri, Al-Moamary, Al-Takroni, Roberts, \& van der Vleuten, 2012). The authors conclude with recommendation of an effective training program to promote the desired students' study strategies, either through modifying the curriculum or the supervisory role, among other strategies (Al-Kadri et al., 2012). In a similar study on medical students, researchers in their findings conclude that students using construction study strategies were superior in performance compared to their peers applying rote and review process (Ensminger, Hoyt, Chandrasekhar, \& McNulty, 2013). The above research pose a point of interest for students in courses such as business management which has little lab or clinical aspect in their curriculum. These students need to understand that perhaps their usage of study strategies, such as rote and review process, would not assist them when they transition to the working world. In future employment, a more suitable study strategy could be construction study or deep learning strategies, with feedback aspects to provide information for improving performance. This section analyzed strategies for studying a groups of subjects based on the curriculum. The next section focuses on one subject in particular, English, both written and oral.

The literature on strategies to learn English, especially for non-native speakers, suggest that strategies for students learning English could be divided into metacognitive, cognitive or socioaffective strategies (O'Malley, Chamot, Stewner-Manzanares, Russo, \& Kupper, 1985). Metacognitive involve taking active actions while learning languages, especially planning, 
monitoring and self-assessment during the learning process (O’Malley et al., 1985). Cognitive strategies on students concentration on the data itself and transformation of the data (Brown \& Palincsar, 1982). Socioaffective strategies focus on cooperation and clarification actions (O'Malley et al., 1985). In their study, O'Malley et al. (1985) came to the conclusion, language learning strategies and general studying strategies may have little difference in broad terms. Other researchers however are of the opinion that strategies of learning English has more categories, from six dimensions (Oxford, 2003,) to seven (Anderson, 2003) (Rahimi \& Katal, 2012). In a review, Rahimi and Katal (2012), suggest that metacognitive strategies, that is being conscious what one was doing, might lead to successful learning strategies. Metacognitive lead students to 'plan, control and evaluate' their learning (Rahimi \& Katal, 2012). The authors suggest that more research is required in this area, especially aligning types of strategies used, successful strategies and learner characteristics (Rahimi \& Katal, 2012).

Language learning strategies could have a major impact on academic achievement (Abdul Razak, Ismail, Abdul Aziz, \& Babikkoi, 2012). The authors note that in Malaysia, for example, in the secondary school system, students who used learning strategies aided reading comprehension (Ganakumaran, 2003). Motivation is an important factor with regard to future independent learning strategies - students who are motivated would be willing to use appropriate strategies and practise independently (Abdul Razak et al., 2012). In the authors' study of student learning strategies, using Oxford (1990) six domains learning strategies, the research found that secondary students in Malaysia used all six learning strategies - including metacognitive, affective and cognitive strategies. This section had focused on language learning strategies, combining both oral and written. However, the issue of particular interest to Malaysian employers - as had been previously discussed- was the fluency of speaking English. The next section looks at the literature focused on English fluency among students and graduates.

The low level of fluency of English speaking of Chinese graduates is the focus on Liu's (2013) paper. The author noted that historically, several factors could explain the low level of competency, among them is the focus of more on reading compared with listening and speaking skills (Liu, 2013). The author focuses on self-efficacy beliefs in the study in analyzing students' own strategies to achieve improvement in English speaking fluency. The area of research on self-efficacy beliefs and language learning is established based on the belief that self-efficacy has an impact on language learning capability. Researchers noted that Bandura (1997) stated that self-efficacy refers to "beliefs in one's capabilities to organize and execute the course of action required to produce given attainments" (as cited in Liu, 2013).

Liu (2013) noted several studies that have reported the positive relationship between self-efficacy and achievement (Tilfarlioğlu \& Ciftci, 2011), reading capability (Mills, Pajares and Herron, 2006) as well as listening (Rahimi \& Abedini, 2009). Liu's study (2013) reveal that students with higher self-efficacy tended to visit the English Bar to practice English more often than those who had lower levels. Liu (2013) noted that a possible fact that compel students of all levels of proficiency to visit the English Bar to improve their English was that in China, graduates with fluency in English tended to have a higher probability of getting a 
job in a competitive environment. Liu (2013) concluded that the success of the English Bar suggest that activities outside the classroom could improve proficiency in English as some students might be unwilling to talk in class, or intimidated by the formalness of the classroom. In addition, students also had access to native speakers to practice with, in an informal environment.

The inability to speak might suggest fluency in English might suggest cultural backgrounds effect. But some research indicates otherwise. In a study by Zhiping and Paramasivan (2013), international postgraduate students were interviewed on reasons for anxiety in speaking English in class and their strategies for coping. The findings of the study indicate that of the three nationalities, Iranian, Algerian and Nigerian, Nigerian students had less anxiety due to their background of learning English during their primary education as well as English being a second language. For Algerian and Iranian students, their background with English education was different, and thus suffers higher levels of anxiety. Thus the authors' conclude that anxiety of speaking English was less related to cultural background but more to learning skills and coping strategies.

This section had discussed the literature on language learning strategies with regard to English language. Several strategies from the literature had been presented, ranging from learning models for general studying, to language learning strategies ranking between three to six domains, which include metacognitive, cognitive and affective strategies. In addition, focusing on fluency of English speaking, the literature noted the importance of self-efficacy beliefs, and that cultural backgrounds play a less dominant role compared to the access to English language courses during primary education. Nevertheless, similarity between countries like Malaysia and China, is where fluency in speaking English, could determine the difficulty or otherwise of landing a job soon after graduation.

The above literature had shown the dominance of the 'outside' factors in implementing programs or assessment of programs in either language learning or general studying strategies. In other words, the success of students' learning was based on the relationship between the student and the teacher and the teachers' strategies and efforts. Programs were implemented by teachers or administrators and students' were assessed on their usage of various strategies. A question that might be raised would be: What are the strategies that the students would do on their own? In another way, if no programs were implemented, what would be their students' own strategies, on their own initiative, on their own time, on their own effort and on their own funding?

The above literature had focused on the learning that had occurred at the students' level, based on the efforts of outside actors: teachers and administrators. A possible study could be exploring the students' own experiences and their reasoning on the strategies that they use or not use in developing their English language capability, particularly English language fluency. The next section briefly introduces a model based on the area of supply chain management that could be used as a model to analyze students' own strategies towards building their capabilities. 


\section{Supplier Learning}

To compete, companies need to ensure they have sustainable competitive advantage. One such advantage is focusing on the integrated supply chain- managing suppliers efficiently, which could lead to a three-year gap before competitors could achieve similar levels (Bovel $\&$ Martha, 2000). When buyers outsource to suppliers, buyers are linking the capabilities and performance of suppliers to the performance of their own firms, thus ensuring that a buyer-supplier relationship is established (Carr et al., 2008). Wagner and Hoegl (2006) have found that buyers divide suppliers into two major categories: 'know-how' (have specialised knowledge) and 'capacity' (knowledge is less important). Other than a firm's own internal learning, other sources of learning could come from close relationships and collaborations with business partners such as suppliers or buyers (Huang, Kristal, \& Schroeder, 2008) training and staff inputs (Huang et al., 2008), as well as organisational knowledge transfer (tacit learning) occurs through supplier training and visits ( Modi \& Mabert, 2006).

Yet, some researchers suggest there is a need to understand how suppliers learn (Othman et al., 2005; Li, Humphreys, Yeung, \& Cheng, 2007). One model that could be used to understand supplier learning is the Pyramid Model: Capability development and Funding (Abdul Kadir, Tam, \& Ali, 2011). This model focuses on the internal factors and external factors that suppliers face when they are building their capability and learning. This model suggest that in early periods when suppliers are involved in supplier development programs with their buyers, training programs tended to be simpler, more elementary and implemented by outside actors (for example, government training programs). However, as the suppliers build their capability and become part of a supplier network, they then have access to their buyers' knowledge capability as well as their buyers' technical partners. Then, as they become more specialized, they build relationships with their own technical partners, focusing on niche areas. Then later, at the final pinnacle, they become their own masters in building their capability and are able to do the process on their own. The figure below gives a simple flow of the model:

\begin{tabular}{|l|}
\hline A Simplified Pyramid Model: Capability Development and Funding \\
\hline Level 4 - Own Funding: Develop Own Technology \\
\hline Level 3- Mix of Own and External Funding: Niche Technology \\
\hline Level 2- Buyer and Government Funding: Mainstream Technology \\
\hline Level 1-Government Funding: External Training, General Technology \\
\hline
\end{tabular}

Figure 1. Simplified Pyramid Model

Source: Abdul Kadir et al., 2011.

The above model could be extrapolated as a framework to analyse the experiences of students own strategies in learning English as they prepare for employment. The assumption would be the years in schools and higher learning institutions, including universities, would be related 
to Level 1. Thus, as a student intend to improve his/her capability, how far are they in their effort to achieve the highest level? Between Level 1 (maximum assistance) and Level 4(least assistance), beliefs such as self-efficacy could be a possible motivator to move the individual up through the levels.

Thus, this paper suggest that future research could use the above model as a framework to analyse the level of independence in the strategies that are used by future graduates to improve their English language fluency as they prepare for employment. In addition, it would be interesting if students who have achieved Level 4, have higher future job performance compared with other students, in a longitudinal study. Practitioners and people in the industry could also use the model as a framework on building training programs to improve English language fluency among their staff.

\section{Conclusion}

This paper had presented an overview of the language learning strategies, beginning with the impetus of the current education policy in Malaysia and the needs of the industry with regard to fluency of English language among its employees. Three areas of literature had been discussed in detail: competencies and graduate employment, language learning strategies and supplier learning, and the pyramid model. This paper concludes with future research area in analyzing the own strategies of students - outside the classroom and on their own time and money. What are they doing? Why are they doing it? The pyramid model of capability development and funding could be a possible framework for analysis of research findings. Using the model, practitioners could design their training programs, and in the decision of 'make-or-buy', would be able to 'make' their own employees to fulfill the language criteria that they need.

\section{Acknowledgement}

The authors gratefully acknowledge the support of grant funding from Universiti Utara Malaysia (University Grant, S/O: 12574).

\section{References}

Abdul Kadir, K., Tam, O. K., \& Ali, H. (2011). Pattern of supplier learning: Malaysian automotive industry case studies. Asian Academy of Management Journal, 16, 23-42.

Abdul Razak, N. Z., Ismail, F., Abdul Aziz, A., \& Babikkoi, M. A. (2012). Assessing the use of English language learning strategies among secondary school students in Malaysia. Procedia Social and Behavioral Sciences, 66, 240-246. http://dx.doi.org/10.1016/j.sbspro.2012.11.266

Al Kadri, H. M., Al-Moamary, M. S., Elzubair, M., Magzoub, M. E., AlMutairi, A., Roberts, C., \& van der Vleuten, C. (2011). Exploring factors affecting undergraduate medical students' study strategies in the clinical years: a qualitative study. Advances in health sciences education, 16(5), 553-567. http://dx.doi.org/10.1007/s10459-010-9271-2

Al-Kadri, H. M., Al-Moamary, M. S., Al-Takroni, H., Roberts, C., \& van der Vleuten, C. P. 
(2012). Self-assessment and students' study strategies in a community of clinical practice: A qualitative study. Med Educ Online, 11204. http://dx.doi.org/10.3403/meo.v17i0.11204

Anderson, N. (2003). Metacognitive reading strategies increase L2 performance. The Language Teacher, 27, 20-22.

Bandura, A. (1997). Self-efficacy: The exercise of control. New York: W. H. Freeman and Company.

Bovel, D., \& Martha, J. (2000). From supply chain to value net. Journal of Business Strategy, 21, 24-28. http://dx.doi.org/10.1108/eb040101

Broadbent, D. (1966). The well-ordered mind. American Educational Research Journal, 3, 281-295. http://dx.doi.org/10.3102/00028312003004281

Brown, A. L., \& Palincsar, A. S. (1982). Inducing strategic learning from texts by means of infomred, self-control training. Topics in learning and learning disabilities, 2, 1-17.

Carr, A. S., Kaynak, H., Hartley, J. L., \& Ross, A. (2008). Supplier dependence: Impact on supplier's participation and performance. International Journal of Operations and Production Management, 28, 899-916. http://dx.doi.org/10.1108/01443570810895302

Ensminger, D. C., Hoyt, A. E., Chandrasekhar, A. J., \& McNulty, J. A. (2013). Changes in study strategies of medical students between basic science courses and clerkships are associated with performance. Journal of Education and Learning, 2(4), 77-86. http://dx.doi.org/10.5539/jel.v2n4p77

Entwistle, N., \& McCune, V. (2004). The conceptual bases of study strategy inventories. Educational Psychology Review, 16, 325-345. http://dx.doi.org/10.1007/s10648-004-0003-0

Ganakumaran, S. (2003). Literature programmes in Malaysian schools: A historical overview. In S. Ganakumaran (Ed.), Teaching of Literature in ESL/EFL contexts (pp. 27-48). Petaling Jaya: Sasbadi.

Huang, X., Kristal, M. M., \& Schroeder, R. G. (2008). Linking learning and effective process implementation to mass customization capability. Journal of Operations Management, 26, 714-729. http://dx.doi.org/10.1016/j.jom.2007.11.002

Ismail, R., Yussof, I., \& Lai, W. S. (2011). Employers' perceptions on graduates in Malaysian services sector. International Business Management, 5, 184-193. http://dx.doi.org/10.3923/ibm.2011.184.193

Li, W., Humphreys, P. K., Yeung, A. C. L., \& Cheng, T. C. E. (2007). The impact of specific supplier development efforts on buyer competitive advantage: An empirical model. International Journal of Production Economics, 106, 230-247. http://dx.doi.org/10.1016/j.ijpe.2006.06.005

Liu, M. (2013). English bar as a venue to boost students' speaking self-efficacy at the tertiary level. English Language Teaching, 6(12), 27-37. http://dx.doi.org/10.5539/elt.v6n12p27 
Marthandan, G., Jayashree, S., \& Yelwa, H. A. (2013). Acquiring key competencies in Malaysia. Proceedings of the 23rd International Business Research Conference, 18-20 November. Melbourne: World Business Institute.

Mills, N., Pajares, F., \& Herron, C. (2006). A reevaluation of the role of anxiety: Self-efficacy, anxiety and their relations to reading and listening proficiency. Foreign Language Annuals, 39(2), 276-294. http://dx.doi.org/10.1111/j.1944-9720.2006.tb02266.x

Ministry of Education Malaysia. (2012). Malaysia Education Blueprint 2013-2025. Ministry of Education Malaysia.

Modi, S. B., \& Mabert, V. A. (2006). Supplier development: Improving supplier performance through knowledge transfer. Journal of Operations Management, 25, 42-64. http://dx.doi.org/10.1016/j.jom.2006.02.001

O'Malley, J. M., Chamot, A. U., Stewner-Manzanares, G., Russo, R. P., \& Kupper, L. (1985). Learning strategy applications with students of English as a second language. TESOL Quarterly, 19, 557-584. http://dx.doi.org/10.2307/3586278

Othman, S. N., Mohammad, N., \& Bakar, N. A. (2005). Technology transfer for developing suppliers' technological capability. Journal of Technology Management and Entrepreneurship, $3,1-18$.

Oxford, R. (1990). Language Learning Strategies: What Every Teacher Should Know. Englewood Cliffs, NJ: Newbury House.

Oxford, R. (2003). Language learning styles and strategies: An Overview. Oxford: GALA.

Rahimi, A., \& Abedini, A. (2009). The interface between EFL learners' self-efficacy concerning listening comprehension and listening proficiency. Novitas Royal, 3, 14-28.

Rahimi, M., \& Katal, M. (2012). Metacognitive strategies awareness and success in learning English as a foreign language: an overview. Procedia Social and Behavioral Sciences, 31, 73-81. http://dx.doi.org/10.1016/j.sbspro.2011.12.019

Sarji, A. A. (1993). Malaysia's Vision 2020: Understanding the Concept, Implications and Challenges. Petaling Jaya: Pelanduk Publications.

Sarudin, I., Mohd Noor, Z., Zubairi, A. M., Tunku Ahmad, T. B., \& Nordin, M. S. (2013). Needs assessment of workplace English and Malaysian graduates English language competency. World Applied Sciences Journal, 21 (Special Issue of Studies in Language Teaching and Learning), 88-94. http://dx.doi.org/10.5829/idosi.wasj.2013.21.slt1.2141

Tilfarlioğlu, F., \& Ciftci, F. (2011). Supporting self-efficacy and learner autonomyin relation to academic success in EFL classrooms (a case study). Theory and Practice in Language Studies, 1, 1284-1294. http://dx.doi.org/10.4304/tpls.1.10.1284-1294

Wagner, S. M., \& Hoegl, M. (2006). Involving suppliers in product development: Insights from R\&D directors and project managers. Industrial Marketing Management, 35(8), 936-943. http://dx.doi.org/10.1016/j.indmarman.2005.10.009 


\section{Macrothink}

Zhiping, D., \& Paramasivam, S. (2013). Anxiety of speaking English in class among international students in a Malaysian university. International Journal of Education and Research, 1, 1-16.

\section{Copyright Disclaimer}

Copyright reserved by the author(s).

This article is an open-access article distributed under the terms and conditions of the Creative Commons Attribution license (http://creativecommons.org/licenses/by/3.0/). 